\title{
Pengembangan tes kemampuan literasi sains pada materi momentum dan impuls dengan Analisis Item Response Theory (IRT)
}

\author{
Della Apriyani Kusuma Putri, Taufik Ramlan Ramalis , dan Purwanto \\ Departemen Pendidikan Fisika, Universitas Pendidikan Indonesia \\ J1. Dr. Setiabudhi 229 Bandung 40154, Indonesia \\ Surat-e: akpdella@gmail.com
}

\begin{abstract}
Kemampuan literasi sains adalah suatu kemampuan yang memungkinkan seseorang untuk membuat suatu keputusan dengan pengetahuan konsep dan proses sains yang dimilikinya. Berbagai macam permasalahan yang terjadi di era globalisasi ini menuntut siswa untuk tidak hanya cakap dalam aspek kognitif tapi juga mampu memberi keputusan untuk memecahkan permasalahan, sehingga dapat dikatakan bahwa kemampuan literasi sains adalah kemampuan yang penting dan harus dimiliki siswa. Oleh karena itu, dibutuhkan instrumen untuk mengukur kemampuan literasi sains. hal inilah yang mendasari peneliti mengembangkan instrumen kemampuan literasi sains. Tujuan penelitian ini adalah untuk mengembangkan dan mengetahui karakteristik tes kemampuan literasi sains fisika siswa SMA pada materi momentum dan impuls berdasarkan aspek literasi sains yang dikemukakan oleh Gormally. Metode penelitian yang diterapkan adalah penelitian dan pengembangan (Research and Development) yaitu metode penelitian yang digunakan untuk menghasilkan produk tertentu, dan menguji keefektifan produk tersebut. Sebelum diuji coba tes telah divalidasi oleh tiga orang validator dan menghasilkan kesimpulan bahwa tes cukup baik dan dapat diuji coba. Hasil analisis menggunakan Item Response Theory menunjukkan bahwa model 3PL adalah model yang sesuai dengan karakteristik tes. Sedangkan karakteristik tes yang meliputi daya pembeda, tingkat kesukaran, dan faktor tebakan termasuk dalam kategori baik.
\end{abstract}

Science literacy skills is an ability that allows one to make a decision with the knowledge of the concepts and processes of science has. A wide variety of problems that occur in a globalized world requires students to not only proficient in cognitive but also able to make a decision to solve the problem, so it can be said that the ability of science literacy is an important capability and must be owned by the students. Therefore, the instrument is required to measure the ability of science literacy. This problem is underlying instrument researchers develop scientific literacy capabilities. The purpose of this research is to develop scientific literacy proficiency test for high school students on the physics material of momentum and impulse based on aspects of scientific literacy proposed by Gormally. The research method applied is research and development (Research and Development) which is the research methods used to produce a particular product and test the effectiveness of the product. Before tested, the test has been validated by a validator of three people and lead to the conclusion that the test quite well and can be tested. The result using analysis Item Response Theory shows that the model 3PL is a model match to the characteristics of the test. Whereas the characteristics of the test which includes distinguishing, level of difficulty and guess factors included in good categories.

Kata kunci: Kemampuan Literasi Sains, Item Response Theory, Momentum dan Impuls

\section{Pendahuluan}

Ref $[\mathrm{I}]$ menyatakan tujuan pembelajaran sains adalah agar menjadi wadah bagi siswa untuk mempelajari dirinya sendiri dan alam sekitar dan dapat mengaplikasikannya dalam kehidupan sehari-hari. Pernyataan tersebut menyirat bahwa pembelajaran sains tidak hanya ditujukan agar siswa mendapat pengetahuan yang baik dengan mendapatkan nilai kognitif yang tinggi tapi juga menuntut adanya suatu tindakan pengaplikasian ilmu pengetahuan yang telah didapat dalam kehidupan dan interaksinya dengan alam sekitar. Sejalan dengan hal tersebut, rev [2] mengungkapkan bahwa pendidikan pada 
saat ini seharusnya mengarah pada proses kegiatan untuk menghadapi era globalisasi, masalah lingkungan hidup, kemajuan teknologi informasi, konvergensi ilmu dan teknologi, ekonomi berbasis pengetahuan, kebangkitan industri kreatif dan budaya, pergeseran kekuatan ekonomi dunia, serta pengaruh dan imbas teknologi berbasis sains. Semua pendapat yang telah diungkapkan mengacu kepada dibutuhkannya suatu kemampuan literasi sains sebagai hasil dari kegiatan pembelajaran dan pendidikan sains yang telah didapatkan siswa, keterampilan literasi sains dapat diartikan sebagai keterampilan seseorang untuk membedakan fakta-fakta sains dari bermacam-macam informasi, mengenal dan menganalisis menggunakan metode penyelidikan saintifik serta kemampuan untuk mengorganisasi, menganalisis, menginterpretasikan data kuantitatif dan informasi sains [3]. Fisika adalah salah satu cabang ilmu sains yang penggunaannya sangat dekat dengan kehidupan sehari-hari dan berbagai permasalahan yang terjadi saat ini merupakan permasalahan yang jalan keluarnya dapat dianalisis dengan menggunakan ilmu fisika. Oleh karena itu, setelah mempelajari fisika siswa diharapkan memiliki kemampuan literasi sains sehingga dapat memecahkan permasalahan yang terjadi di lingkungan sekitar dengan ilmu fisika yang dimiliki.

Sejalan dengan hal tersebut, pentingnya kemampuan lliterasi sains telah disadari oleh pemerintah Indonesia dibuktikan dengan diterapkannya kurikulum 2013 revisi. Kurikulum 2013 revisi terdiri dari Kompetensi Inti (KI) yang terdiri dari 3 aspek, aspek sikap terdapat pada KI I dan 2, aspek pengetahuan pada KI 3, dan aspek keterampilan terdapat pada KI 4. Melihat komponenkomponen dalam model literasi sains Graber [4], kompetensi-kompetensi inti dalam kurikulum 2013 revisi telah mengarah pada tercapainya literasi sains. Apabila kompetensi-kompetensi inti dalam kurikulum 2013 revisi dipetakan dalam model literasi sains Graber, maka KI I dan KI 2 masuk dalam komponen "what people value", KI 3 masuk dalam komponen "what people know", dan KI 4 masuk dalam komponen "what people do". Maka dapat dikatakan bahwa kurikulum 2013 revisi yang diterapkan oleh beberapa sekolah di Indonesia saat ini telah termasuk dalam kategori model literasi sains menurut Graber.

Keberhasilan siswa dalam mempelajari literasi sains dapat dilihat dari baik atau tidaknya nilai yang didapat siswa pada tes yang diberikan guru. Hasil penilaian tersebut nantinya dapat dijadikan bahan evaluasi untuk pembelajaran selanjutnya. Pernyataan tersebut sejalan dengan Permendikbud Nomor 23 tahun 2016 yang mengungkapkan bahwa penilaian adalah proses pengumpulan dan pengelolaan informasi untuk mengukur pencapaian hasil belajar peserta didik dengan tujuan memantau dan mengevaluasi proses, kemajuan belajar, dan perbaikan hasil belajar, dan perbaikan hasil belajar peserta didik dengan cara berkesinambungan. Berdasarkan pernyataan tersebut dapat dikatakan bahwa diterapkannya penilaian selama ini dalam dunia pendidikan memiliki tujuan dan manfaat bagi kemajuan pendidikan ke depannya, karena dengan diterapkannya penilaian masalah yang terjadi pada kegiatan pembelajaran dapat diketahui dan diperbaiki pada pembelajaran selanjutnya sehingga berujung pada suatu kesimpulan bahwa penilaian perlu diterapkan dalam setiap aspek pendidikan. Dalam penerapannya penilaian membutuhkan instrumen untuk mengukur ketercapaian hasil belajar siswa, salah satunya berupa tes. Tes merupakan alat untuk mendapatkan informasi karakteristik suatu objek. Objek di sini dapat berupa kemampuan peserta didik, sikap, minat, maupun motivasi [6].

Namun, berdasarkan hasil studi pendahuluan yang berupa wawancara kondisi di lapangan masih belum sesuai dengan apa yang diharapkan. Adapun hasil wawancara kepada dua orang guru di salah satu SMA di kota Bandung menunjukkan bahwa kemampuan literasi sains belum diukur dengan tes yang tepat. Penilaian yang dilakukan oleh guru hanya sebatas pada penilaian yang ditentukan pemerintah dalam kurikulum pembelajaran yaitu penilaian kognitif, afektif, dan psikomotorik. Mengenai keterampilan literasi sains guru tetap menerapkannya namun dalam pengukurannya dimasukan ke dalam penilaian afektif.

Berdasarkan kepada hasil studi pendahuluan tersebut dapat dikatakan bahwa ada ketidak sesuaian antara apa yang diharapkan dengan keadaan sebenarnya yang terjadi di lapangan. Oleh karena itu, peneliti menganggap bahwa keterampilan literasi sains dan tes yang mengukurnya adalah objek yang perlu diteliti. Sehingga dibutuhkannya tes yang tidak hanya tepat untuk mengukur keterampilan literasi sains tapi juga memiliki kualitas yang baik.

Kualitas butir soal penyusun tes yang baik dapat dilihat dari karakteristik tes yang terdiri dari daya pembeda, tingkat kesukaran, dan faktor tebakan. Karakteristik tes dapat diketahui dengan dua pendekatan teori yakni teori klasik dan teori respon butir. Namun dalam mengkarakteristik tes, teori klasik memiliki beberapa kelemahan seperti yang disebutkan oleh Rev [7] dan Rev [8] diantaranya adalah: I) statistik butir tes sangat tergantung pada karakteristik subjek yang di tes; 2) taksiran kemampuan peserta tes sangat bergantung pada tes yang disajikan; 3) kesalahan baku penaksir skor berlaku untuk semua peserta tes, sehingga kesalahan baku pengukuran tiap peserta dan butir soal tidak ada; 4) informasi yang disajikan terbatas pada jawaban benar atau salah tidak memperhatikan pola jawaban peserta tes; dan 5) asumsi tes paralel susah dipenuhi.

Berdasarkan kelemahan yang dimiliki teori klasik maka dikembangkanlah teori respon butir atau Item Response Theory (IRT), kelebihan dari IRT apabila dibandingkan dengan teori klasik antara lain: I) IRT tidak berdasarkan grup dependent, 2) skor siswa dideskripsikan bukan skor 
dependent, 3) model ini menekankan pada tingkat butir soal bukan tes, 4) IRT tidak memerlukan paralel tes untuk menentukan reliabilitas tes, 5) IRT suatu model yang memerlukan suatu pengukuran ketepatan untuk setiap skor tingkat kemampuan.

Pemaparan yang telah disampaikan di atas merujuk pada suatu kesimpulan bahwa kemampuan literasi sains adalah kemampuan yang penting untuk dimiliki oleh siswa dan untuk mengetahui kualitas butir soal yang baik dapat dilihat melalui karakteristik yang dimiliki tes tersebut melalui analisis Item Response Theory (IRT), peneliti melakukan penelitian dengan judul "Pengembangan Tes Kemampuan Literasi Sains Pada Materi Momentum dan Impuls Dengan Analisis Item Response Theory(IRT)."

\section{Metode Penelitian}

\section{Subjek Penelitian}

Subjek pada penelitian ini adalah 53 siswa kelas XI pada salah satu SMA di kota Bandung yang telah mendapatkan pelajaran momentum dan impuls. Siswa tersebut terdiri atas 17 siswa laki-laki dan 36 orang siswa perempuan.

\section{Desain Penelitian}

Metode penelitian yang digunakan dalam penelitian ini adalah metode penelitian dan pengembangan atau sering disebut juga dengan research and development (R\&D) dengan desain penelitian ADDIE (Analysis, Design, Development, Implementation, dan Evaluation) yang di adopsi dari Dick \& Carey [9]. Tahap-tahap pada penelitian ini secara lengkap dipaparkan sebagai berikut:

\section{Tahap Analysis (Analisis)}

Tahap analisis merupakan tahapan awal pada penelitian untuk mengetahui potensi dan masalah yang terjadi dalam pembelajaran fisika yang berkaitan dengan literasi sains dan pengembangan tes melalui langkahlangkah berikut:

a. Tujuan Penelitian

Tujuan penelitian ini adalah untuk mengembangkan dan mengetahui karakteristik tes keterampilan literasi sains dengan analisis Item Response Theory (IRT) pada materi momentum dan impuls.

b. Studi Literatur dan Studi Pendahuluan

Studi literatur bertujuan untuk mengkaji literatur terkait dengan bahasan pengembangan tes, kemampuan literasi sains, kurikulum 2013 revisi, dan penelitian sebelumnya mengenai pengembangan tes keterampilan literasi sains. Sedangkan studi pendahuluan bertujuan untuk mendapatkan informasi kesesuaian dari literatur yang dikaji dengan kondisi di lapangan, studi pendahuluan melalui wawancara dengan guru.

\section{Tahap Design (Desain)}

Pada tahap desain peneliti memulai rancangan awal soal tes yang terdiri dari menentukan bentuk tes, menentukan aspek literasi sains yang akan digunakan, menentukan indikator, dan merancang kisi-kisi tes. Adapun penjelasan dari langkah-langkah tersebut adalah sebagai berikut:

a. Menentukan Bentuk Tes

Bentuk tes yang digunakan untuk penelitian ini harus didasarkan pada kesesuaian kemampuan yang diukur dalam hal ini adalah kemampuan literasi sains, dan juga mempertimbangkan kelebihan dan kekurangan setiap bentuk jenis tes yang akan digunakan.

b. Menentukan Aspek Kemampuan Literasi Sains Aspek kemampuan literasi sains yang akan digunakan pada penelitian ini adalah aspek kemampuan literasi sains yang dikembangkan oleh Rev [3].

c. Menentukan Indikator

Indikator soal yang disusun berdasarkan kepada aspek literasi sain yang dikembangkan oleh Rev [3] dengan disesuaikan dengan kemampuan peserta didik.

d. Merancang Kisi-Kisi

Rancangan kisi-kisi disajikan dalam bentuk tabel, dalam tabel terdapat poin-poin seperti aspek literasi sains, indikator, butir soal, dan kunci jawaban.

\section{Tahap Development (Pengembangan)}

Tahap pengembangan adalah tahap dimana produk tes dihasilkan setelah melewati tahapan validasi dari ahli dan proses revisi. Berikut ini adalah rincian dari tahap pengembangan penelitian:

a. Validasi Ahli

Hasil dari kisi-kisi yang telah dirancang tersebut kemudian divalidasi oleh tiga orang validator yang terdiri dari dua orang dosen dan I orang guru. Hasil dari validasi tersebut kemudian dianalisis menggunakan indeks Aiken $\mathrm{V}$ untuk mengetahui apakah soal tersebut sudah baik atau perlu dilakukan perbaikan.

b. Revisi Produk

Setelah dilakukan validasi oleh ahli yang meliputi aspek validasi isi maka peneliti melakukan revisi terhadap soal tes sesuai dengan masukan yang diberikan oleh validator. 
4. Tahap Implementation (Implementasi)

Pada tahap ini soal tes yang sudah dikembangkan diuji coba secara terbatas kepada siswa SMA yang telah menerima pelajaran momentum dan impuls.

\section{Tahap Evaluation (Evaluasi)}

Hasil dari uji coba terbatas kemudian dievaluasi dengan menggunakan analisis IRT. Hasil analisis tersebut meliputi validitas, reliabilitas, daya pembeda, tingkat kesukaran, dan faktor tebakan.

\section{Instrumen Penelitian}

Instrumen yang digunakan pada penelitian karakteristik tes keterampilan literasi sains antara lain sebagai berikut:

I. Wawancara

Wawancara yang digunakan dalam penelitian ini adalah jenis wawancara terstruktur. Dalam melakukan wawancara peneliti telah menyiapkan pedoman pertanyaan terkait dengan informasi yang ingin didapatkan peneliti terkait pengembangan tes kemampuan literasi sains dan untuk memudahkan proses wawancara peneliti menggunakan alat bantu seperti recorder pada telepon genggam.

\section{Lembar Judgement}

Lembar judgment digunakan untuk mengetahui kualitas soal yang telah dirancang oleh peneliti untuk mengukur validasi isi. Lembar judgement kemudian diisi oleh validator yang terdiri dari dua orang dosen dan satu orang guru dengan memberikan tanda checklist $(\checkmark$ ) pada kolom yang sesuai. Kemudian hasil dari validasi tersebut dianalisis dengan menggunakan indeks Aiken $\mathrm{V}$ untuk mengetahui validitas dari tes yang dibuat.

\section{Tes Keterampilan Literasi Sains}

Tes keterampilan literasi sains yang dikembangkan dalam penelitian ini mengacu pada literasi sain yang dikemukakan oleh Gormally. tes terdiri dari 35 soal pilihan ganda dan empat pilihan jawaban. Setelah tes melalui tahap uji coba terbatas, tes di analisis menggunakan IRT dengan bantuan eirt versi 2.0.0.

\section{Hasil Penelitian dan Pembahasan}

Uji coba terbatas yang telah dilakukan di salah satu SMA kota Bandung yang memiliki akreditasi A dengan sampel berjumlah 53 siswa kelas XI SMA yang telah mendapat pelajaran momentum dan impuls dianalisis dengan IRT menggunakan bantuan eirt 2.0.0. untuk mendapatkan kecocokan model parameter logistik, reliabilitas, dan karakteristik tes yang terdiri dari daya pembeda, tingkat kesukaran, dan faktor tebakan.

\section{Fungsi Informasi Total}

Kesesuaian model parameter logistik (MPL) dapat dilihat dari fungsi informasi total. MPL yang memiliki puncak informasi paling tinggi adalah MPL yang sesuai untuk tes. Fungsi informasi total disajikan pada Gambar 4.I berikut.

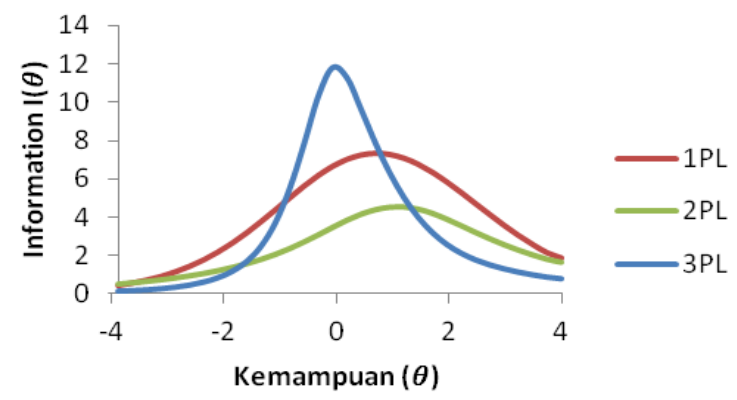

Gambar I. Grafik Fungsi Informasi Total Model IPL, 2PL, dan 3PL

Berdasarkan grafik di atas dapat dilihat bahwa MPL yang memiliki puncak paling tinggi pada grafik fungsi informasi total adalah model 3PL yang mencapai puncak maksimum di $I(\theta)=11,29$ pada saat kemampuan $(\theta)=0,19$. Ini berarti model 3PL merupakan model yang sesuai dan dapat dipilih untuk analisis butir.

Grafik 3PL di atas menunjukan bahwa nilai kemampuan peserta $(\theta)$ tes yang diukur terletak di antara $-3,87$ dan +4 , rentang kurva tersebut memiliki arti bahwa peserta tes bervariasi yang terdiri dari kemampuan rendah, sedang, dan tinggi. Pada grafik tersebut terlihat pada peserta tes kemampuan rendah informasi yang didapat dari pengukuran juga rendah demikian juga dengan peserta tes berkemampuan tinggi). Pada peserta tes kemampuan sedang, informasi yang didapatkan dari pengukuran tinggi. $\mathrm{Hal}$ ini menunjukkan tes menghasilkan informasi yang maksimal pada peserta tes berkemampuan sedang.

\section{Karakteristik Tes}

Karakteristik tes total adalah butir soal tes yang meliputi daya pembeda, tingkat kesukaran, dan faktor tebakan. Karakteristik tes total dapat dilihat dari kurva karakteritik total atau Total Characterictic Curve (TCC) model 3PL. Hal pertama yang perlu dilakukan untuk mengetahui karakteristik total tes adalah dengan membuat garis lurus secara vertikal dan horizontal mendekati grafik TCC pada suatu titik yang menunjukan skala kemampuan agar peluang menjawab benar sebesar 50\%, kemudian membuat garis asimtot yang melewati titik tersebut. sehingga terbentuklah gambar grafik seperti Gambar 4.2 berikut. 


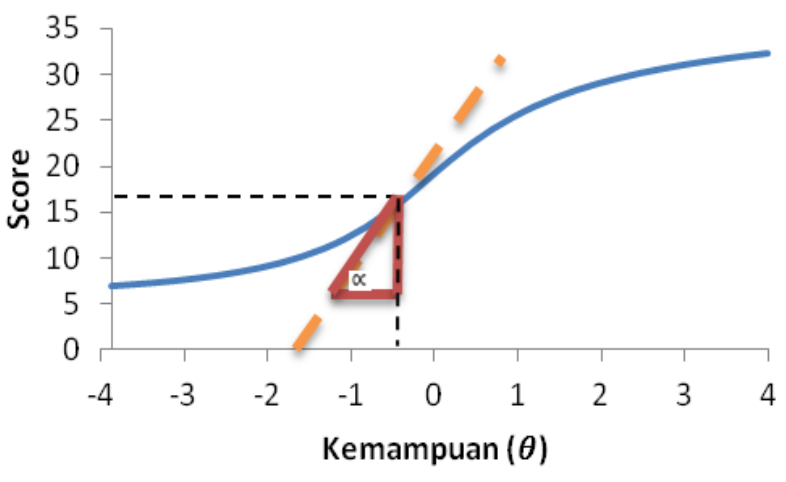

Gambar 2. Grafik TCC 3PL

Pada grafik TCC di atas skala kemampuan agar peluang menjawab benar sebesar 50\% terdapat pada titik skala kemampuan 19,66. Selanjutnya untuk mengetahui daya pembeda, tingkat kesukaran, dan faktor tebakan yaitu dengan menganalisis grafik TCC yang telah diolah tersebut.

Daya pembeda (a) didapatkan dari nilai $\tan \alpha$ yaitu sebesar I,92. Nilai daya pembeda tersebut dapat dikatakan berkategori baik karena berada diantara rentang 0 sampai +2 .

Tingkat kesukaran (b) didapatkan dari garis vertikal yang berada pada kemampuan peserta tes (sumbu-x), grafik CTT pada model 3PL menunjukkan nilai sebesar 0,32 . Sehingga dapat dikatakan tingkat kesukaran tes berada pada kategori baik karena berada diantara rentang -2 sampai +2 . Tingkat kesukaran tes memiliki arti kemampuan siswa untuk menjawab tes, semakin besar nilai tingkat kesukaran, maka semakin besar kemampuan yang diperlukan untuk menjawab benar dengan peluang $50 \%$. Dengan kata lain semakin besar nilai tingkat kesukaran, maka makin sulit tes tersebut untuk dijawab.

Faktor tebakan (c) menggambarkan probabilitas peserta tes dengan kemampuan rendah menjawab dengan benar pada butir yang memiliki tingkat kesukaran yang tidak sesuai dengan kemampuan peserta tes tersebut. Pada penelitian ini nilai faktor tebakan sebesar 0,2I, karena syarat faktor tebakan dikatakan baik apabila berada diantara rentang 0 sampai +I maka dapat dikatakan faktor tebakan pada penelitian termasuk dalam kategori baik karena berada pada rentang tersebut.

\section{Reliabilitas dan Validitas Tes}

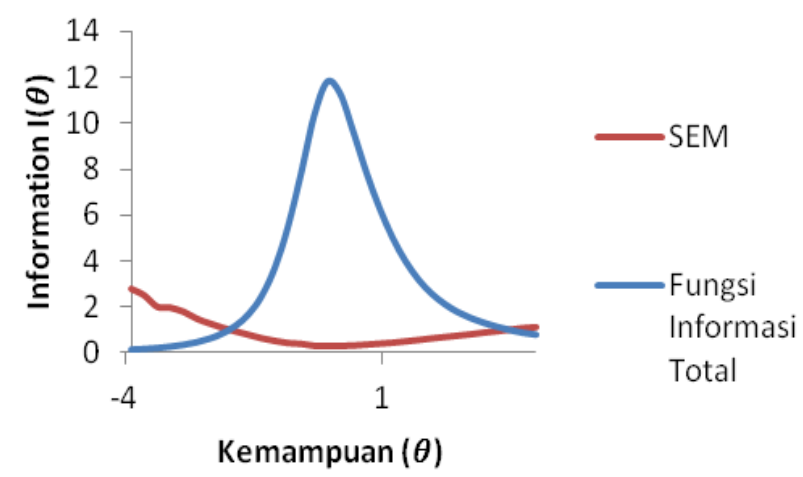

Gambar 3. Grafik Fungsi Informasi Total dan SEM Model 3PL

Reliabilitas tes dan validitas tes dapat diketahui dari perpotongan SEM dengan fungsi informasi. Berdasarkan Gambar 4.3 tersebut dapat dikatakan bahwa tes akan reliabel apabila diberikan kepada siswa dengan kemampuan dalam rentang kemampuan -I,84 sampai 3,49 dan termasuk dalam kategori cukup valid.

\section{Kesimpulan}

Dari penelitian pengembangan tes kemampuan literasi sains pada materi momentum dan impuls dengan analisis Item Response Theory (IRT) adalah sebagai berikut:

I. Fungsi informasi total tes yang didapat menunjukan model parameter logistik yang sesuai dengan karakteristik tes adalah model 3PL dengan puncak maksimum di $I(\theta)=11.29$ pada saat kemampuan $(\theta)=0.19$.

2. Berdasarkan kurva karakteristik total (CCT) yang telah diolah didapatkan karakteristik tes yaitu daya pembeda sebesar sebesar I,92, tingkat kesukaran sebesar -0,32, dan faktor tebakan sebesar 0,2I. Ketiga karakteristik tes tersebut termasuk kedalam kategori baik.

3. Reliabilitas tes yang didapat dari perpotongan fungsi informasi total dengan SEM berada pada rentang I,84 sampai 3,49 dan validitas yang termasuk dalam kategori cukup baik.

\section{Saran}

Saran peneliti bagi penelitian sejenis yang hendak melakukan penelitian pengembangan tes kemampuan literasi sains dengan Analisis IRT adalah sebagai berikut:

I. Sampel penelitian diusahakan lebih dari 50 orang agar model parameter yang didapatkan adalah model 3PL sehingga karakteristik tes yang dapat diukur adalah daya pembeda, tingkat kesukaran, dan faktor tebakan. 
Selain itu jumlah sampel yang lebih banyak juga akan menambah tingkat reliabel tes.

2. Sebelum melakukan uji coba hal yang perlu diperhatikan bukan hanya kunci jawaban yang tepat, butir soal yang memiliki satu kunci jawaban, dan kejelasan kompetensi yang diukur saja tapi juga pastikan pengecoh dapat berfungsi dengan baik dan materi yang ditanyakan tidak terlalu sulit sehingga karakteristik yang didapat berkategori baik.

\section{Ucapan Terimakasih}

Peneliti mengucapkan terima kasih kepada Bapak Dr. Taufik Ramlan Ramalis, M.Si. dan Bapak Drs. Purwanto, MA. yang senantiasa memberikan arahan, masukan, dan motivasi kepada peneliti selama melaksanakan penelitian ini. Terima kasih pula peneliti ucapkan kepada seluruh pihak yang membantu baik secara langsung maupun tidak langsung pada awal proses penelitian hingga penelitian ini selesai dilaksanakan.

\section{Kepustakaan}

[I] BNSP (2006). Panduan Penyusunan Kurikulum Tingkat Satuan Pendidikan Jenjang Pendidikan Dasar dan Menengah. Jakarta: BNSP. http://bsnp-indonesia.org/wpcontent/uploads/kompetensi/Panduan_Umum_KTSP.pdf

[2] Asyhari, A \& Hartati, R. (2015). Profil Peningkatan Kemampuan Literasi Sains Siswa Melalui Pembelajaran Saintifik. Jurnal Ilmiah Pendidikan Fisika 'Al-biruni', 4 (2), hlm. I79-19I.

[3] Gormally, C., Brickman, P \& Lutz, M. (2012). Developing a Test of Scientific Literacy Skills (TOLS): Measuring Undergraduates Evaluatio of Scientific Information Arguments. CBE-Life Science Education. II, hlm. 364-377.

[4] Holbrook, J, \& Rannikmae, M. 2009. The Meaning of Scientific Literacy. International Journal of Environmental \& Science Education, 4 (3), 275- 278.

[5] Permendikbud (2016.) Nomor 23 Tahun 2016 Tentang Standar Penilaian Pendididkan.

[6] Eko Putro Widoyoko. (201I). Evaluasi Program Pembelajaran. Yoyakarta: Pustaka Pelajar.

[7] Hambleton, R. K., Swaminathan, H., \& Rogers, H. J. (I99I). Fundamentals of item response theory. Newbury Park, CA: Sage.

[8] Lord, F. M. (1980). Applications of item response theory to practical testing problems. Hillsdale, NJ: Lawrence Erlbaum.

[9] Dick and Carey. 1996. The Sistematic Design of Instruction. Fourth Edition: Harper Collins College Publisher. 